\title{
APPLICATION OF LANDSAT IMAGERY AND VEGETATION INDEX PROPERTY TO ASSESS THE SHORELINE CHANGES ALONG COX'S BAZAR-TEKNAF COAST
}

\author{
Umme Kulsum Navera* and Md. Safin Ahmed \\ Department of Water Resources Engineering, BUET, Dhaka-1000, Bangladesh
}

Received: 09 May 2019

Accepted: 01 November 2020

\begin{abstract}
Bangladesh is located at the head of the Bay of Bengal. The coast of Bangladesh is known as a zone of vulnerabilities as well as opportunities which involves coast and island boundaries. The eastern coastal zone consists of sandy beaches and hilly areas and is morphologically very dynamic. This shoreline is an important zone which facilitates tourism opportunity, fishing industry, natural resources and regional highway. Cox's Bazar-Teknaf shoreline has been experiencing severe erosion at a number of places due to wave action. Wave and wind induced motion results in sediment distribution and shaping of nearshore morphology. The study has been performed by using Remote Sensing and GIS techniques. The shoreline shifting analysis has been performed by the process of open source Landsat images from 1980 to 2017. Satellite derived band algebra; Normalized Difference Vegetation Index has been utilized to identify the vegetation cover. The satellite images of an object carry a unique index property. In this study the index property of vegetation cover has been used to delineate more stable shorelines. At different locations, the average change in shoreline goes up to $120 \mathrm{~m}$ in erosion and $100 \mathrm{~m}$ in deposition. Based on the coastline shifting the erosion behaviour and the vulnerable areas are identified.
\end{abstract}

Keywords: Geographic Information System; Landsat Imagery; NDVI; Remote Sensing; Shoreline.

\section{INTRODUCTION}

Coastal zones are interfaces of land and ocean adjusting geosphere, climate and biosphere (Enmark, 2007) and these dynamic areas comprise the natural boundary between land and ocean (Lazin, 2016). The coastal zone is composed of the coastal plain, continental shelf and water that covers the shelf. It also includes other major features such as large bays, lagoons, coastal dune fields, river estuaries and deltas (Inman et al., 1973; Crossland et al., 2005; Fedra et al., 1988).

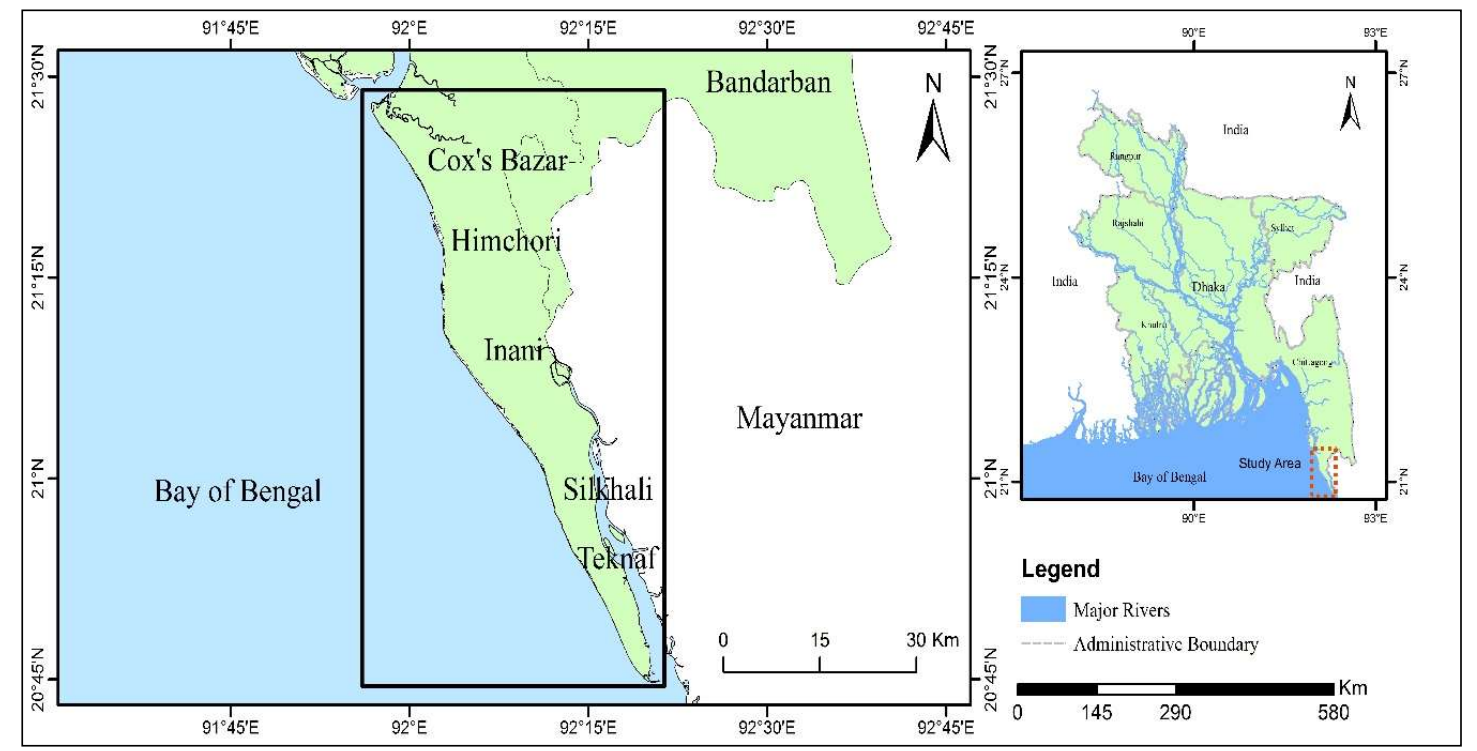

Figure 1: Location map of the study area

An area of 47,201 $\mathrm{Km}^{2}$ is covered by the coastal Zone of Bangladesh (WARPO, 2006). This coastal area has abundance of resources and has been developed for a wide variety of purposes including settlement, agriculture, fisheries, tourism and communication (Alam et al., 1999). Approximately 46 million people lives in the coastal 
zones and it comprises 2.85 million hectares of cultivable land (Bala and Hossain, 2010). This coastal zone provides $20 \%$ of the rice production (Begum and Fleming, 1997). The coastal zone of Bangladesh is different from the rest of the country due to its unique geo-physical characteristics. These zones are vulnerable due to several natural disasters like erosion, deposition, cyclone, storm surges, sea level rise, settlement and also various forms of pollution (Akter, 2015).

The impact of growing population and development along the shoreline have been greatly discussed in the literature such as in Cendrero (1989), Turner et al. (1996) and UN (2003). Understanding coastal processes and beach morpho-dynamics to evaluate the shoreline changes is a scientific goal as well as a requirement to support coastal management plans (Galgano \& Leatherman, 1991; Honeycutt et al., 2001; Pajak \& Leatherman, 2002). It is important to understand the shoreline changes in different time scales (short and long) to identify the priority areas (such as erosion prone areas) for coastal management (Esteves, 2004). The shoreline changes has been calculated in this study in two different ways, (i) short term changes represents the changes in the same point between two nearest years (1980-1989, 1989-1993, 1993-1996, 1996-2000, 2000-2004, 2004-2006, 2006-2010, 2010-2013 and 2013-2017), and (ii) long term shoreline changes has been computed in the same point based on a base year which is 1980 with all the mentioned different years $(1989,1993,1996,2000,2004,2006,2010,2013$ and 2017).

The study area consists $85 \mathrm{~km}$ of sandy beach line from Cox's Bazar to Teknaf (Figure 1). The image analysis has been carried out by using Landsat images and the erosion or deposition has been detected in every $500 \mathrm{~m}$ interval throughout this $85 \mathrm{~km}$ Shoreline.

\section{DATA AND METHODOLOGY}

The spatial and temporal changes in shoreline of coastal areas can be evaluated qualitatively and quantitatively by using historic maps, aerial photographs, remote sensing and GIS technique, beach profiles, topographic and bathymetric surveys. These datasets might provide a variety of means to analyse the rate of changes of shoreline position. Remote Sensing and Geographic Information System (GIS) can quantify the coastal processes, erosion and accretion especially in the last decades and this is well documented now (Durduran, 2010; Sener et al., 2010). Different methods for coastline extraction from optical imagery have been developed (Bosworth et al., 2003; Di et al., 2003; Foody et al., 2005; Dewidar and Frihy, 2008). It has become critical to assess the amount of erosion and accretion for the management of coastal zone and socio-economic developments in the coastal areas. Shoreline delineation is a complex and time-consuming task. Shoreline variability as well as trend analysis depends largely on the accuracy of shoreline delineation. However, during the demarcation of shoreline, temporal and spatial dimensionality must be taken care of (Islam et al., 2014).

Table 1: Satellite images used for this study

\begin{tabular}{|c|c|c|c|c|}
\hline Satellite & Sensor & $\begin{array}{c}\text { Band } \\
\text { Composite }\end{array}$ & $\begin{array}{l}\text { Spatial Resolution of } \\
\text { Band Composite (m) }\end{array}$ & Year \\
\hline \multirow{9}{*}{ Landsat } & \multirow[t]{4}{*}{ MSS } & \multirow{4}{*}{$2,3,4$} & \multirow[t]{4}{*}{60} & 19 February 1980 \\
\hline & & & & 22 February 1989 \\
\hline & & & & 25 February 1993 \\
\hline & & & & 18 February 1996 \\
\hline & \multirow[t]{4}{*}{$\mathrm{TM}$} & \multirow[t]{4}{*}{$3,4,5$} & \multirow[t]{4}{*}{30} & 29 February 2000 \\
\hline & & & & 8 February 2004 \\
\hline & & & & 13 February 2006 \\
\hline & & & & 8 February 2010 \\
\hline & OLI & $4,5,6$ & 30 & $\begin{array}{c}21 \text { April } 2013 \\
11 \text { February } 2017\end{array}$ \\
\hline
\end{tabular}

The objective of the present study is to measure the spatial and temporal shifting of shoreline by using multi temporal satellite data. This study will also find the dynamic nature of the Cox's Bazar-Teknaf shoreline and will identify the vulnerable zones along the shoreline. In this context, geospatial techniques i.e., the Remote Sensing and Geographic Information System (GIS) have been used. Multi-temporal Landsat satellite images of the study area have been acquired by optical sensors during the dry season (February-April) from 1980 to 2017 (Table 1) were downloaded from Earth Explorer. Dry period satellite images were chosen because vegetation cover and other ground conditions, particularly the water level, are relatively consistent during the dry season, which is essential for assessing the inter-year change of erosion and accretion (Hossain et al., 2013). 


\subsection{Satellite Images Analysis}

The remotely sensed satellite images have been analysed by using Geographic Information System (GIS). All satellite images were projected onto the Bangladesh Transverse Mercator (BTM) projection system, whose specifications are: (1) Ellipsoid $=$ Everest 1830, (2) Projection $=$ Transverse Mercator, (3) Central meridian $=90^{\circ}$ $\mathrm{E}$, (4) False easting $=500,000 \mathrm{~m}$ and (5) False northing $=2,000,000 \mathrm{~m}$ (ISPAN, 1992). The analysis of the images started with the digitization of the shorelines from all satellite images. All selected satellite images have been carefully analysed for shorelines and vegetation covers using the ArcView GIS software.

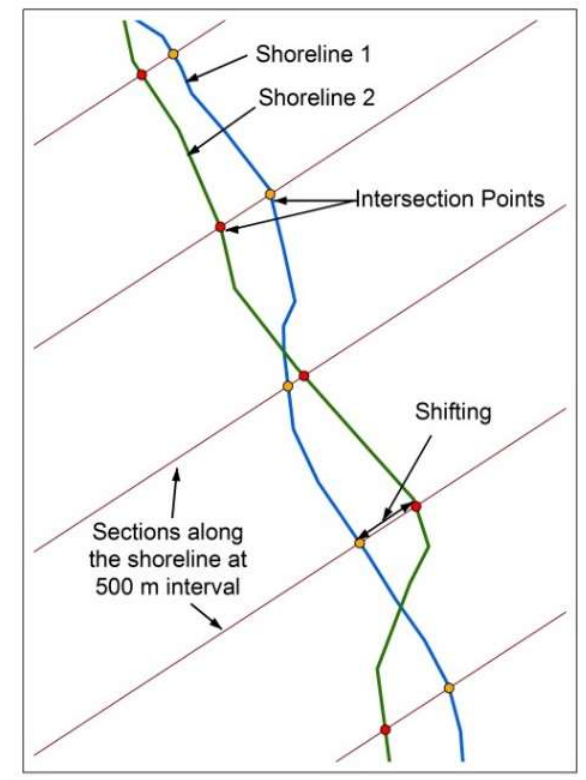

Figure 2: Schematic diagram of shoreline movement

Figure 2 describes the Schematic diagram of shoreline movement from 1980-2017 and similar method was used by Hossain et al. (2013). To quantify the changes in shoreline at different locations a total of 166 transects at 500 $\mathrm{m}$ intervals along the $85 \mathrm{~km}$ study reach have been digitized and coordinate points between the shoreline and transects have been determined.

\subsection{Shoreline Shifting}

Shoreline is the interface between the land and the sea. It is dynamic and it's spatial position changes over many time scales (Moore, 2000). Shoreline changes depict the way of shoreline movement, movement direction and rate. The shoreline may move landwards through the process of erosion; or seawards by sediment accretion (Boak and Turner, 2005). Shoreline changes can be estimated over different time scales ranging from geological to diurnal (WIOMSA, 2015). It is a highly challenging task to identify the cause of shoreline changes without field measurement, but Remote Sensing and GIS technique provides an opportunity to quantify the shoreline changes by image analysis.

\subsection{NDVI calculation}

The Normalized Difference Vegetation Index (NDVI) is a numerical indicator that uses the visible and nearinfrared bands of the electromagnetic spectrum to observe green vegetation. NDVI was first used in 1973 by Rouse et al. from the Remote Sensing Centre of Texas A\&M University. Generally, healthy vegetation will absorb most of the visible light that falls on it, and reflects a large portion of the near-infrared light. Unhealthy or scattered vegetation reflects more visible light and less near-infrared light on the other hand, uncovered soils reflect moderately in both the red and infrared segment of the electromagnetic spectrum (Holme et al., 1987). The NDVI algorithm subtracts the red reflectance values from the near-infrared and divides it by the sum of near-infrared and red bands.

$$
N D V I=\frac{(N I R-R e d)}{(N I R+R e d)}
$$


Theoretically, calculations of NDVI for a given pixel always result in a number that ranges from minus one (-1) to plus one $(+1)$; in practice extreme negative values represent water, values around zero represent bare soil and close to $+1(0.8-0.9)$ indicates the highest possible density of vegetation (Weier and David, 2000).

\section{RESULTS AND DISCUSSION}

The shifting of the Cox's Bazar-Teknaf shoreline with respect to transects has been calculated. Table 2 and Table 3 show the average value within the specified time and the maximum values indicate the highest value within the same time period for the total study reach. The positive value indicates deposition and negative value denotes the amount of erosion.

Table 2: Short term shoreline shifting due to deposition and erosion

\begin{tabular}{ccccc}
\hline \multicolumn{3}{c}{ Deposition $(\mathrm{m})$} & \multicolumn{2}{c}{ Erosion $(\mathrm{m})$} \\
\hline Year & Average & Maximum & Average & Maximum \\
\hline $1980-1989$ & 60.69 & 174.93 & -102.13 & -380.56 \\
$1989-1993$ & 72.29 & 405.10 & -20.92 & -57.75 \\
$1993-1996$ & 35.03 & 141.43 & -55.64 & -219.50 \\
$1996-2000$ & 82.92 & 309.10 & -36.85 & -110.43 \\
$2000-2004$ & 50.08 & 218.87 & -81.32 & -352.82 \\
$2004-2006$ & 23.72 & 121.45 & -32.57 & -149.80 \\
$2006-2010$ & 111.92 & 322.71 & -50.82 & -141.01 \\
$2010-2013$ & 37.35 & 277.94 & -59.68 & -245.74 \\
$2013-2017$ & 28.65 & 89.72 & -57.41 & -380.40 \\
\hline
\end{tabular}

Table 3: Long term shoreline shifting due to deposition and erosion

\begin{tabular}{ccccc}
\hline & \multicolumn{3}{c}{ Deposition $(\mathrm{m})$} & \multicolumn{2}{c}{ Erosion $(\mathrm{m})$} \\
\hline Year & \multicolumn{1}{c}{ Average } & Maximum & Average & Maximum \\
\hline $1980-1989$ & 60.69 & 174.93 & -102.13 & -380.56 \\
$1980-1993$ & 68.37 & 269.39 & -64.21 & -174.76 \\
$1980-1996$ & 88.04 & 250.79 & -97.96 & -276.75 \\
$1980-2000$ & 57.59 & 363.20 & -94.80 & -253.12 \\
$1980-2004$ & 80.26 & 184.95 & -100.64 & -411.95 \\
$1980-2006$ & 87.54 & 378.11 & -114.79 & -311.71 \\
$1980-2010$ & 72.71 & 529.64 & -79.55 & -344.32 \\
$1980-2013$ & 56.55 & 263.99 & -73.47 & -431.88 \\
$1980-2017$ & 97.20 & 420.45 & -96.77 & -326.62 \\
\hline
\end{tabular}

Table 2 depicts the short term changes in the shore line which has been calculated beweeen two consecutive taken year. The highest deposition occured during the period 1989-1993 where as the maximum erosion happened in between 1980 to 1989. Table 3 illustrates the longterm chenges which has been calculatd based on the year 1980 for this study. In both erosion and deposition cases the maximum rate does not follow any specific pattern.

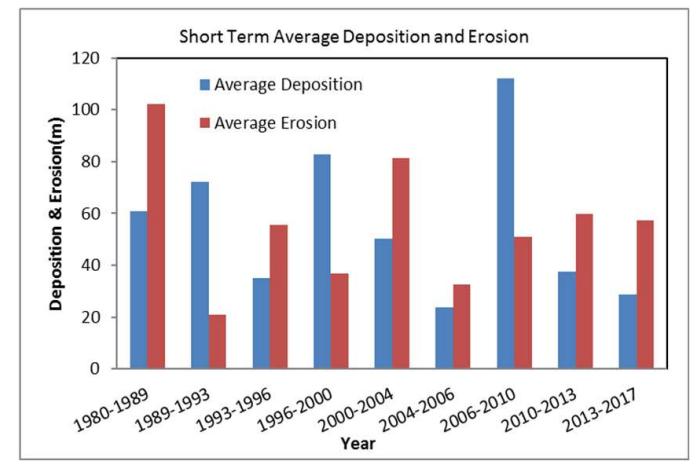

Figure 3: Changes in short time deposition and Erosion

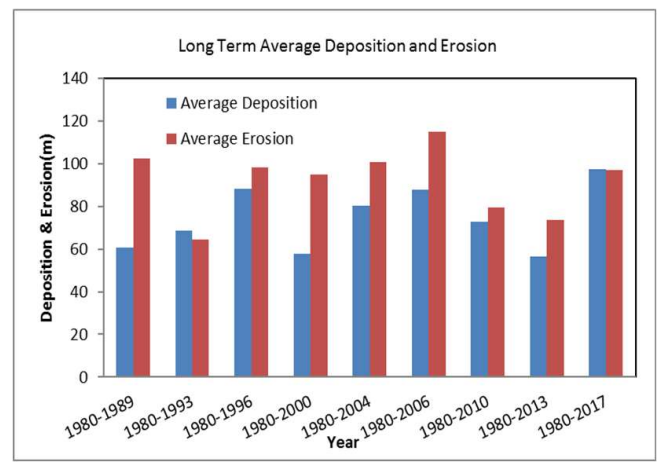

Figure 4: Changes in long time deposition and Erosion

FIGURE 3 and FIGURE 4 describe the short and long-term average deposition and erosion amount through the $85 \mathrm{~km}$ long shoreline. From Figure 3 it has been found that there is dramatic change in the amount of erosion and deposition. The total area of deposition and erosion dominates alternatively till the year of 2010 and after the year 
2010 the value of erosion has increased whereas the amount of deposition has decreased. This indicates a net increasing in erosion for last 7 years.

Figure 5 illustrates the changes in deposition and erosion along the shoreline between Cox's bazar and Teknaf. It has been found that Himchari area which is about $12 \mathrm{~km}$ from Cox's Bazar, is the most vulnerable area where the maximum amount of erosion occurs during the selected period of analysis.

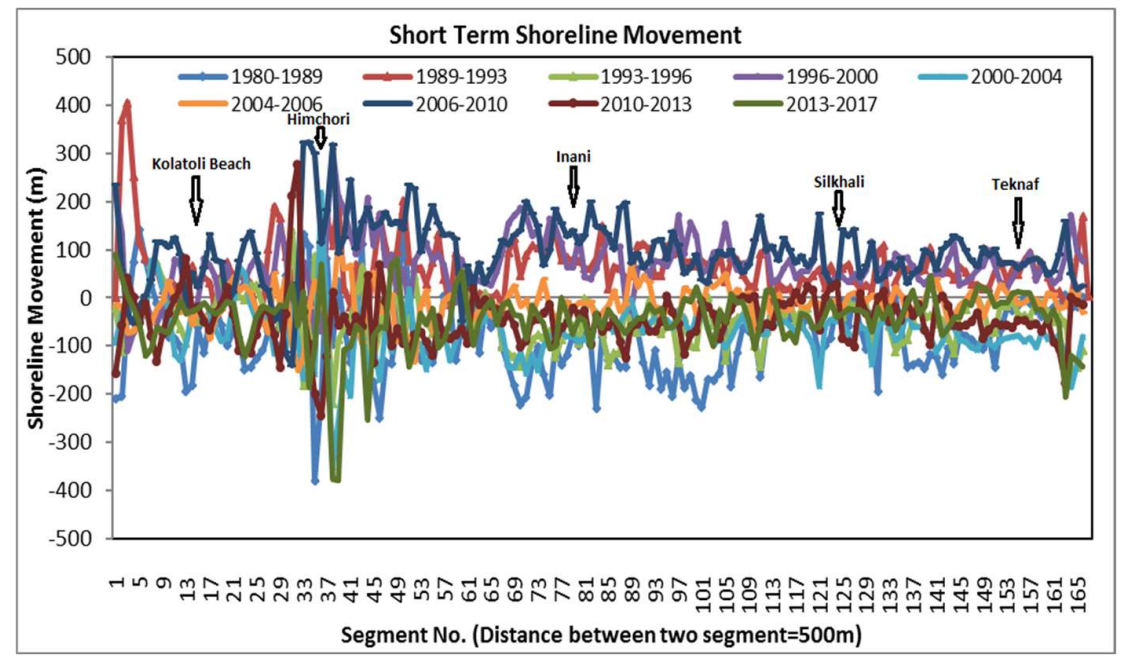

Figure 5: Changes in shoreline between Cox's bazar and Teknaf

The total length of the study area has been divided into three sub-sections to identify the shoreline changes clearly which are shown in Figure 6 and this figure also presents the shoreline changes for last 37 years. Figure 7, Figure 8 and Figure 9 depict the short time shoreline changes in different years and it has been found that the highest erosion occurred in between section $A-A$ and $B-B$. The shoreline during the year 2004-2006 shows minimum average deposition $(23 \mathrm{~m})$ and the maximum deposition occurs during the year 2006-2010 which is around 112 $\mathrm{m}$. The maximum erosion $102 \mathrm{~m}$ occurred during the period 1982-1989 and the minimum erosion $20 \mathrm{~m}$ occurred during 1989-1993.

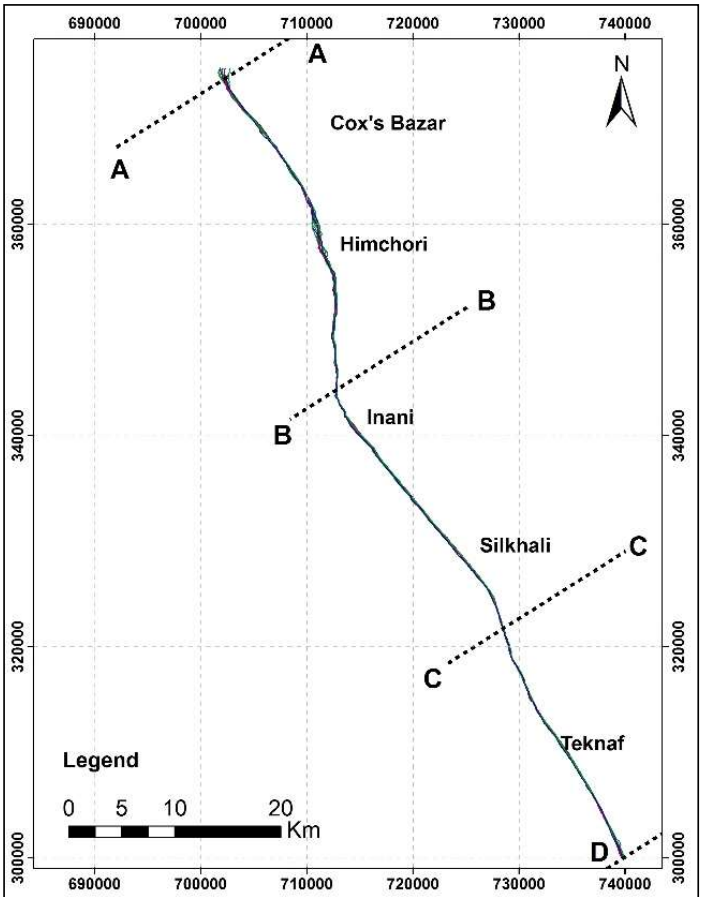

Figure 6: Shorelines of different years between Cox's bazar and Teknaf

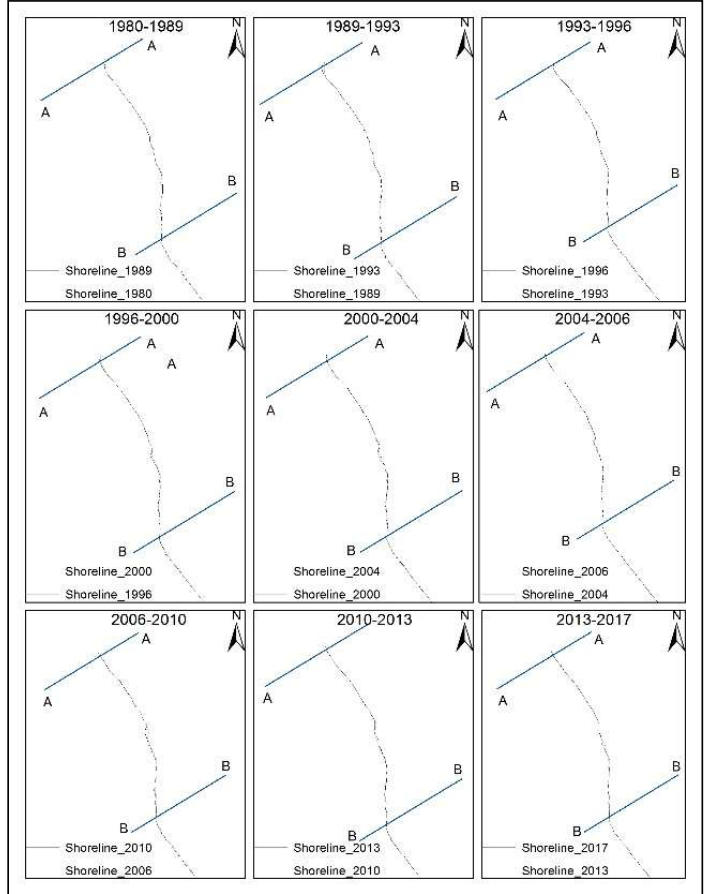

Figure 7: Short term shoreline shifting within section A-A and B-B 
Figure 10 illustrates the NDVI values for the respective years considered and it can be clearly visible from the figures that areas having lower NDVI values (less vegetation) are more susceptible to shoreline changes, which indicates that the areas are more dynamic in nature. The areas with high NDVI values (high vegetation coverage) are more stable in the study area.

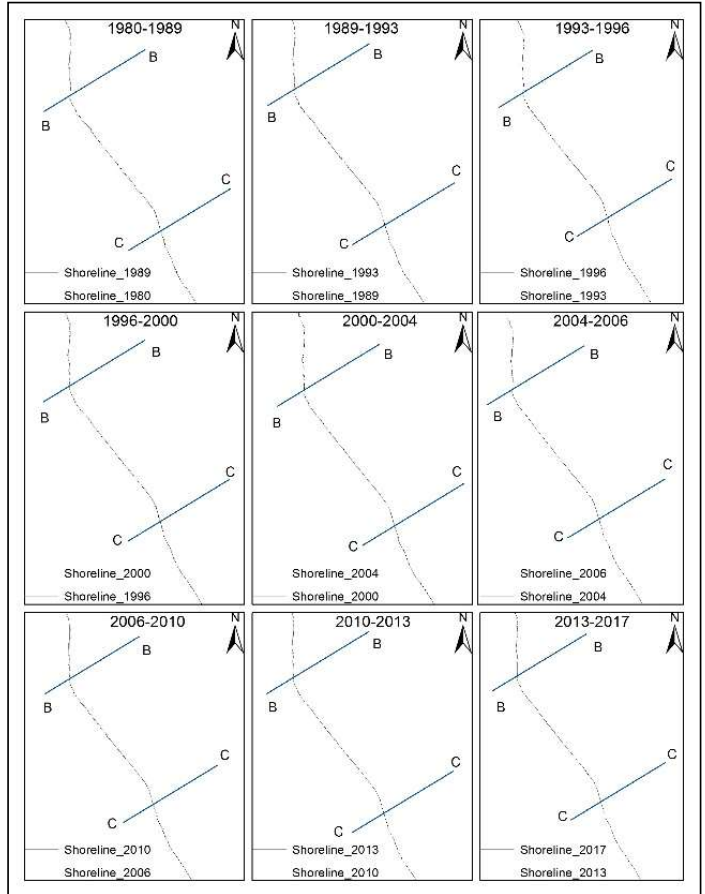

Figure 8: Short term shoreline shifting within section B-B and C-C

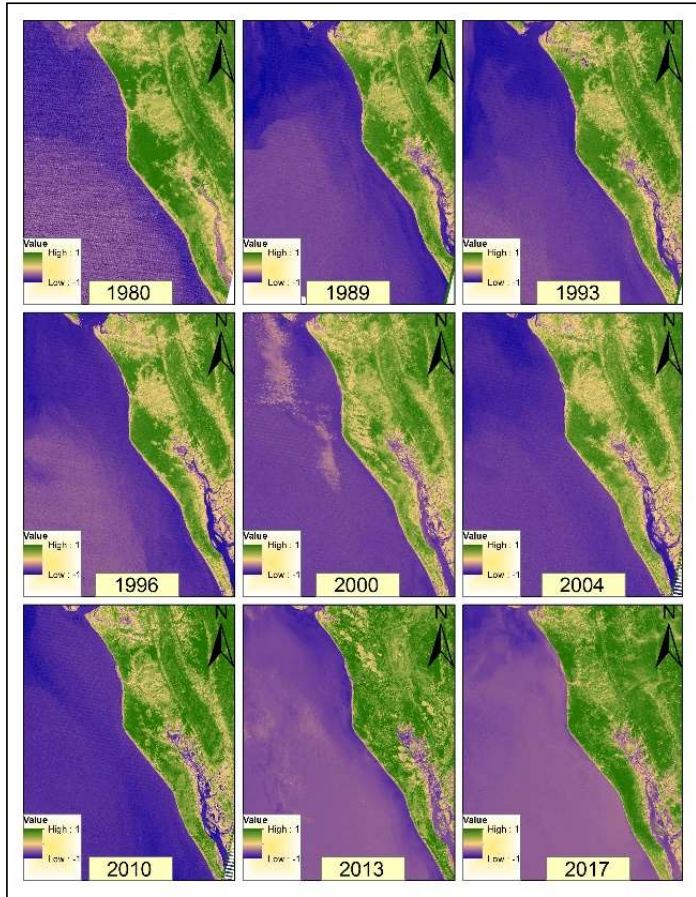

Figure 10: NDVI values within the study reach

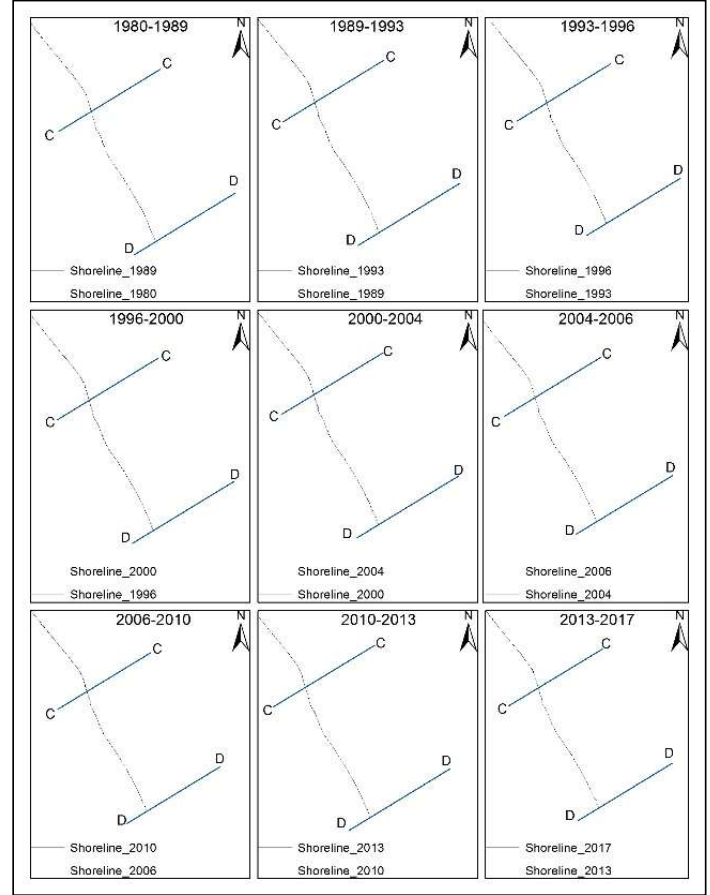

Figure 9: Short term shoreline shifting within section C-C and D-D

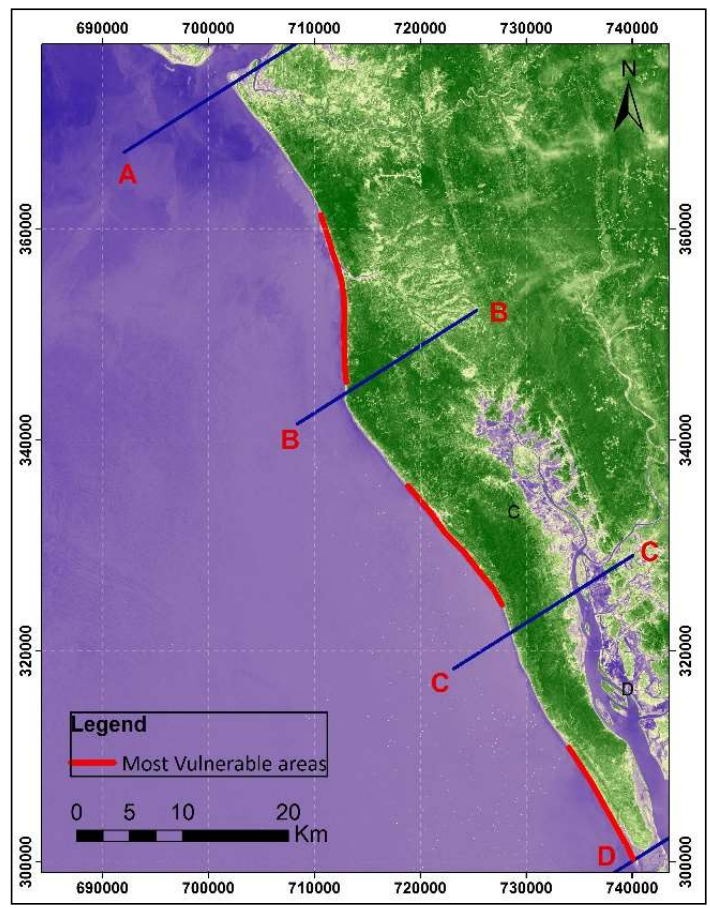

Figure 11: Most vulnerable areas within the study reach 
Figure 11 highlights the most dynamic and vulnerable locations along the Cox's Bazar-Teknaf shoreline. From this figure it can be said that there is considerable shifting almost in every sections. Maximum erosion and deposition has been found near Himchori area. The Inani region is also very dynamic in nature.

\section{CONCLUSION}

The Cox's Bazar-Teknaf shoreline is found to be very dynamic in nature. From the time series analysis of Landsat imagery from 1980 to 2017, it has been found that the shoreline shifting occurs with respect to every transect lines. For the different 3 segments, the shoreline shifting rate is found to be higher in the section A-A and B-B during last 37 years. Based on the results of this study it can be said that special shore protection measures need to be taken for the current and future planning and management of Cox's Bazar-Teknaf shoreline. All the concerning protection works or defensive mechanism for any development project should be taken without disturbing the natural coastal processes that has been going on from time immoral.

\section{REFERENCES}

Akter, S., 2015. Assessment of Nearshore Hydrodynamic Process along the Coasts of Cox's Bazar [thesis], Bangladesh University of Engineering and Technology, pp.54.

Alam, M. D., Huq N. E., and Rashid M. S., 1999. Morphology and Sediments of the Cox's Bazar Coastal Plain South-East Bangladesh, Journal of Coastal Research, 15(4), Royal Palm Beach (Florida), ISSN 07490208, 902-908.

Bala, B., and Hossain M., 2010. Modelling of Food Security and Ecological Footprint of Coastal Zone of Bangladesh, Environ Dev Sustain 12, 511-529

Begum, S., and Fleming G., 1997. Climate change and se level rise in Bangladesh, part II, Effects. Mar Geod (20), 55-68.

Boak, E., and Turner I., 2005. Shoreline definition and detection: A Review. Journal of Coastal Research (21), 688-703

Bosworth, J., Koshimizu T., and Acton S.T., 2003. Multi-resolution segmentation of soil moisture imagery by watershed pyramids with region growing merging, International J. Remote Sensing 24(4), 741-760.

Cendrero, A., 1989. Land-Use Problems, Planning and Management in the Coastal Zone; An Introduction, Ocean and Shoreline Management, 12(5-6), 367-381.

Crossland, C. J., Baird D., Ducrotoy J. P., Lindeboom H., Buddemeier R. W., Dennison W. C., Maxwell B. A., Smith S. V., and Swaney D. P., 2005, The Coastal Zone - a Domain of Global Interactions, Coastal Fluxes in the Anthropocene Global Change - The IGBP Series, Chapter 1, 1-37.

Dewidar, K., and Frihy O. E., 2008. Pre and post-beach response to engineering hard Structures using landsat time-series at the northwestern part of the nile delta, Egypt. J. Coastal Conservation 11(2), 133-142.

Di, K., Wang J., Ma R., and Li R., 2003. Automated shoreline extraction from high resolution IKONOS Satellite Imagery. Proceedings of the ASPRS 2003 Annual Conference, Anchorage, May 2003.

Durduran, S. S., 2010. Coastline change assessment on water reservoirs located in the konya basin area, Turky, using multitemporal Landsat imagery. Environ. Monitoring Assessment (164), 453-461.

Enemark, S., 2007. Coastal Areas and Land Administration - Building the Capacity, Strategic Integration of Surveying Services, $6^{\text {th }}$ FIG Regional Conference 2007, San Jose, Costa Rica, 12-15.

Esteves, L. S., 2004. Shoreline Changes and Coastal Evolution as Parameters to Identify Priority Areas for Management in Rio Grande do Sul, Brazil. Revista Pesquisas em Geociências, Instituto de Geociências, UFRGS. ISSN 1518-2398 Porto Alegre, RS - Brasil, 31 (2), 15-30.

Fedra, K., and Feoli I. M., 1988. GIS Technology and Spatial Analysis in Coastal Zone Management, EEZ Technology, Ed. 3, 171-179.

Foody, G. M., Muslim A. M., and Atkinson P. M., 2005. Super-resolution mapping of the Waterline from remotely sensed data. International J. Remote Sensing 26(24), 5381-5392.

Galgano, F. A., and Leatherman S. P., 1991. Shoreline change analysis: a case study. Coastal Sediments'91 (1), 1043-1053.

Holme, A., Mc R., Burnside D. G., and Mitchell A. A., 1987. The Development of a System for Monitoring Trend in Range Condition in the Arid Shrublands of Western Australia, Australian Rangeland Journal 9, $14-$ 20.

Honeycutt, M. G., Crowell M., and Douglas B. C., 2001. Shoreline position forecasting: impact of storms, ratecalculation methodologies, and temporal scales. Journal of Coastal Research, 17(3), 721-730.

Hossain, M. A., Gan T. Y., Baki A. B. M., 2013. Assessing morphological changes of the Ganges River using Satellite images, doi: 10.1016/j.quaint.2013.03.028, 7-8.

Inman, D. L., and Brush B. M., 1973. The Coastal Challenge, Science, New Series, 181(4094), 20-32. 
Islam, M. A., Hossain M. S., Hasan T., and Murshed S., 2014. Shoreline Changes along the Kutubdia Island, South East Bangladesh Using Digital Shoreline Analysis System, Bangladesh J. Sci. Res. 27(1), 99-108.

ISPAN, 1992, Technical Notes Series 1. ISPAN/USAID, Flood Plan Coordination Organization, Dhaka, Bangladesh

Lazin, R., 2016. Assessment of Nearshore Sediment Transport along Cox's Bazar Coast Using DELFT3D Model [thesis], Bangladesh University of Engineering and Technology, pp.2.

Moore, L., 2000. Shoreline Mapping Techniques, Journal of Coastal Research (16), 111-124.

Pajak, M. J., and Leatherman S., 2002. The high-water line as shoreline indicator, Journal of Coastal Research, 18(2), 329-337.

Roderick, M., Smith R. C. G., and Ludwick G., 1996. Calibrating long term AVHRR derived NDVI imagery. Remote Sensing of Environment (58), 1-12.

Rouse, J. W., Haas R. H., Schell J. A., and Deering D. W., 1973. Monitoring vegetation systems in the Great Plains with ERTS, Third ERTS Symposium, (NASA SP-351), 309-317.

Sener, E., Davraz A., and Sener S., 2010. Investigation of Ak- sehir and Eber Lakes (SW Turky) coastline change with multi temporal Satellite Images. Water Resources Management 24(4), 727-745.

Turner, R. K., Subak S., and Adger W. N., 1996. Pressures, trends and impacts in coastal zones: interactions between socioeconomic and natural systems. Journal of Environmental Management, 20(2), 159-173.

United, Nations International Strategy for Disaster Reduction, 2003. Natural disasters and sustainable development: understanding the links between development, environment and natural disasters, pp.30.

WARPO, 2006. Coastal Development Strategy, Water Resources Planning Organization (WARPO), Ministry of Water Resources, Government of the Peoples Republic of Bangladesh, Dhaka, Bangladesh

Weier, J., and Herring D., 2000. Measuring Vegetation NDVI \& EVI, (www.earthobservatory.nasa.gov) August $30,2000$.

WIOMSA, 2015. Shoreline Change in Tanzania and Kenya, Manual for Assessment and Design of Mitigation Strategies, A Manual prepared under the MASMA (Marine Science for Management) Program of the WIOMSA (Western Indian Ocean Marine Science Association).

(C) 2021 the Authors. Journal of Engineering Science published by Faculty of Civil Engineering, Khulna University of Engineering \& Technology. This is an open access article under the terms of the Creative Commons AttributionNonCommercial-NoDerivatives License, which permits use and distribution in any medium, provided the original work is properly cited, the use is non-commercial and no Modifications or adaptations are made. 